\title{
PEMANFAATAN DIGITAL MARKETING BAGI USAHA MIKRO, KECIL, DAN MENENGAH (UMKM) DI KELURAHAN MALAKA SARI, DUREN SAWIT
}

\author{
Dedi Purwana ES. \\ Universitas Negeri Jakarta, dpurwana@unj.ac.id \\ Rahmi \\ Universitas Negeri Jakarta, rahmi@unj.ac.id \\ Shandy Aditya \\ Universitas Negeri Jakarta, shandy@unj.ac.id
}

\begin{abstract}
The aim of this study is to improve knowledge and skill about digital marketing, especially social media,for Small and Medium-sized Enterprises (SMEs) business maker to enhance their sales and profit. Attended by 13 women SMEs participants, the method used in this activity is; first, explanation using power point slides and LCD projector; second, experience sharing and discussion; and last, direct practice of creating social media (Facebook and Instagram) account and how to make it attractive for buyers (the pictures, the wording, the story, etc). Held on May 7, 2017, the community service is funded by DIPA BLU Faculty of Economics, Universitas Negeri Jakarta. The result shows that only few who actively use social media as their promotion tools and they have not separated their online shop account with their personal account, several others use it occasionally, and the rest participants have never used social media marketing for being lack of technological skill. All participants show great interest to use social media marketing continuously.
\end{abstract}

Key Words: digital marketing, UMKM, social media

\section{PENDAHULUAN}

\section{Analisis Situasi}

Dunia digital diprediksi akan menjadi poin krusial bagi seluruh aktivitas manusia, termasuk aktivitas bisnis. Beberapa indikator yang bisa digunakan saat ini antara lain naiknya pengeluaran iklan digital, pertumbuhan kepemilikan smartphone yang menyediakan kemudahan akses internet, perbaikan infrastruktur telekomunikasi dalam rangka peningkatan 
kualitas akses data, serta diluncurkannya layanan 4G. Menurut data Facebook, 74\% pengguna internet di Indonesia menggunakan perangkat mobile (Utomo, 2016).

Pesatnya perkembangan teknologi, dunia digital dan internet tentu juga berimbas pada dunia pemasaran. Tren pemasaran di dunia beralih dari yang semula konvensional (offline) menjadi digital (online). Strategi digital marketing ini lebih prospektif karena memungkinkan para calon pelanggan potensial untuk memperoleh segala macam informasi mengenai produk dan bertransaksi melalui internet.

Digital marketing adalah kegiatan promosi dan pencarian pasar melalui media digital secara online dengan memanfaatkan berbagai sarana misalnya jejaring sosial. Dunia maya kini tak lagi hanya mampu menghubungkan orang dengan perangkat, namun juga orang dengan orang lain di seluruh penjuru dunia. Digital marketing yang biasanya terdiri dari pemasaran interaktif dan terpadu memudahkan interaksi antara produsen, perantara pasar, dan calon konsumen. Di satu sisi, digital marketing memudahkan pebisnis memantau dan menyediakan segala kebutuhan dan keinginan calon konsumen, di sisi lain calon konsumen juga bisa mencari dan mendapatkan informasi produk hanya dengan cara menjelajah dunia maya sehingga mempermudah proses pencariannya. Pembeli kini semakin mandiri dalam membuat keputusan pembelian berdasarkan hasil pencariannya. Digital marketing dapat menjangkau seluruh masyarakat di manapun mereka berada tanpa ada lagi batasan geografis ataupun waktu.

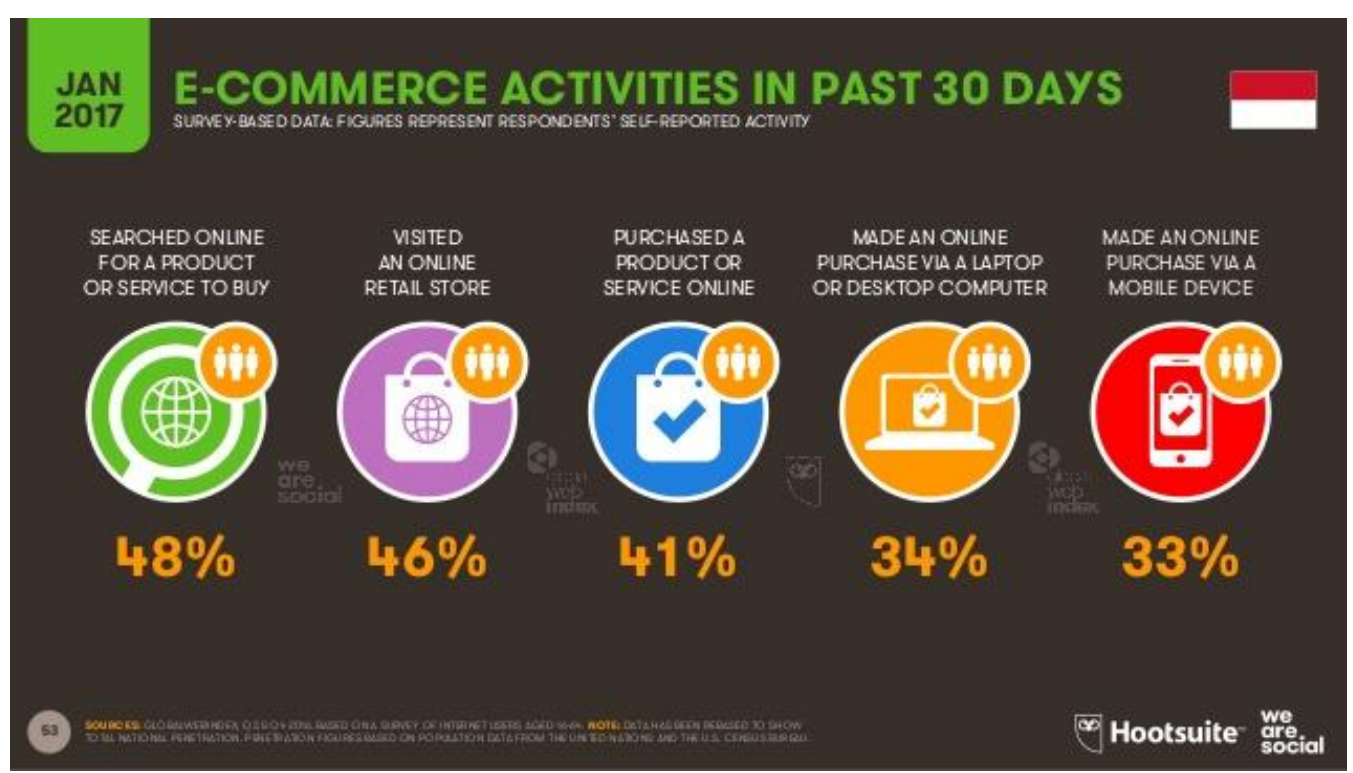

Gambar 1 Aktivitas Belanja Online

Sumber: https://www.slideshare.net/wearesocialsg/digital-in-2017-southeast-asia 
Gambar 1 di atas memaparkan bahwa terhitung sampai Januari 2017, sebanyak $48 \%$ pengguna internet di Indonesia melakukan pencarian barang atau jasa secara online, $46 \%$ pengguna mengunjungi toko online, $34 \%$ pengguna melakukan transaksi online via komputer atau laptop, dan $33 \%$ pengguna melakukan transaksi online melalui perangkat mobile seperti smartphone. Hal ini menyiratkan bahwa potensi belanja online sudah cukup berkembang di Indonesia yang harus diimbangi dengan pemasaran secara digital pula oleh pelaku usaha.

Platform yang sering digunakan dalam digital marketing adalah media sosial atau jejaring sosial. Jejaring sosial yang tersedia terkadang memiliki karakteristik yang berbeda. Ada yang sifatnya untuk pertemanan seperti Facebook, Path, Instagram, dan Twitter, ada pula yang khusus untuk mencari dan membangun relasi seperti yang ditawarkan Linkedin. Selain itu tersedia pula media yang lebih pribadi seperti electronic mail (e-mail) dan pesan teks. Search engine seperti Google dan Yahoo pun dapat diberdayakan. Selain itu pelaku usaha juga dapat memanfaatkan media blog ataupun situs pribadi.

Data yang dilansir oleh We are Social, sebuah agensi digital marketing di Amerika, menyebutkan bahwa platform media sosial yang paling banyak digunakan di Indonesia per Januari 2017 adalah Youtube (49\%) dan oleh Facebook (48\%). Posisi selanjutnya ditempati oleh Instagram (39\%), Twitter (38\%), Whatsapp (38\%), dan Google (36\%). Sisanya ditempati secara berurutan oleh FB Messenger, Line, Linkedin, BBM, Pinterest, dan Wechat (Kemp, 2017).

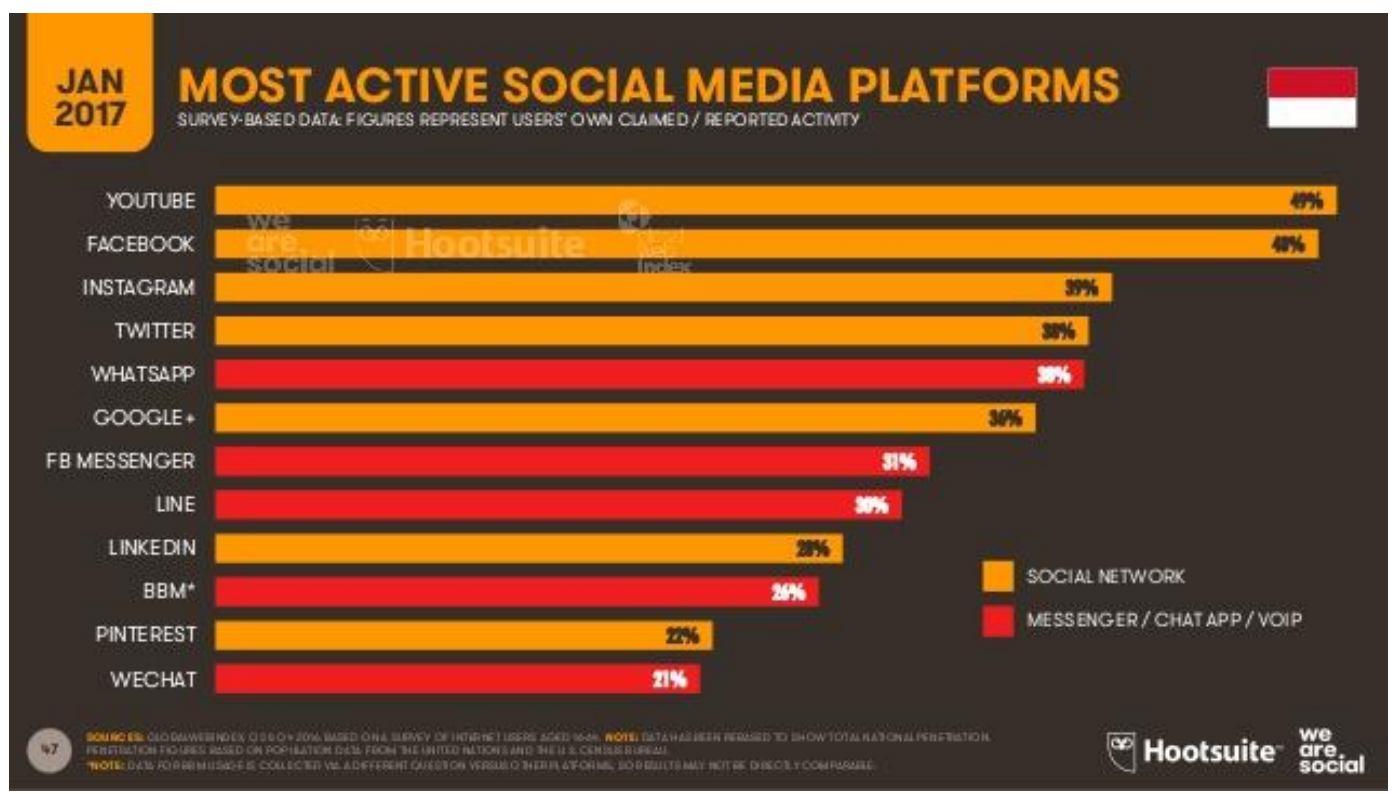

Gambar 2 Platform Media Sosial yang Paling Sering Digunakan di Indonesia Sumber: www.wearesocial.com 
Salah satu perusahaan yang telah membuktikan keefektifan digital marketing adalah Acer Indonesia. Helmy Anam, General Manager Komunikasi dan Pemasaran Acer Indonesia, menyatakan bahwa terjadi kenaikan yang luar biasa di Facebook dan blogger engagement Acer Indonesia mencapai lebih dari $130 \%$ yang menempatkan Acer Indonesia pada posisi pertama dilihat dari "share of voice"(Rahayu, 2012). Ia juga menambahkan bahwa digital marketing merupakan cara komunikasi dua arah yang tidak hanya dapat menimbulkan awareness, namun dapat pula meningkatkan engagement masyarakat terhadap merek Acer.

Sri Widowati, Country Head Facebook Indonesia, menyampaikan bahwa pengguna Facebook di Indonesia membuka halaman Faceboook milik mereka rata-rata 80 kali sehari (Utomo, 2016). Ia juga mengungkap data bahwa sebanyak $45 \%$ pengguna internet di Indonesia lebih suka berbelanja secara online. Angka ini diperkirakan akan terus meningkat seiring dengan pertumbuhan pengguna internet di Indonesia. Hal ini mencerminkan perilaku masyarakat Indonesia yang semakin mengarah ke gaya hidup digital.

Namun peluang ini sepertinya tidak diikuti oleh perubahan perspektif mayoritas perusahaan dan individu yang terlibat dalam dunia digital marketing. Meski perusahaan besar, kecil, maupun individu kini sudah mulai menggunakan digital dan media sosial sebagai salah satu alat berpromosi atau mendekatkan diri kepada konsumen, namun sayangnya jumlahnya masih sangat terbatas. Pemanfaatan pemasaran melalui media digital (digital marketing) masih belum maksimal jika dibandingkan dengan pertumbuhan jumlah pengguna internet yang drastis. Berdasarkan hasil riset McKinsey, baru sekitar 30\% usaha di Indonesia yang menggunakan instrumen digital dalam mengembangkan usahanya (Supriadi, http://www.marketing.co.id, 2016). Melihat hal ini, dapat kita simpulkan bahwa potensi digital marketing di Indonesia masih sangat besar.

Usaha Mikro, Kecil dan Menengah (UMKM) memiliki peran penting dalam laju ekonomi Indonesia terutama dalam penciptaan lapangan kerja dan pemberdayaan rumah tangga yang mendukung pendapatan rumah tangga. Keberadaan UMKM diharapkan mampu memacu perekonomian di tengah perlambatan ekonomi yang terjadi saat ini. Pemanfaatan konsep pemasaran berbasis teknologi digital (digital marketing) memberikan harapan bagi UMKM untuk berkembang menjadi pusat kekuatan ekonomi.

Era digital memang tidak mungkin untuk dihindari. Pakar pemasaran Yuswohadi mengungkapkan bahwa jika ingin bertahan, maka pelaku UMKM harus mampu memaksimalkan manfaat perkembangan digital (Maulana, 2017).

Perkembangan teknologi digital memungkinkan para pelaku UMKM 
untuk memasarkan produknya secara online dan melakukan transaksi melalui sistem perbankan secara online pula.

Menteri Koperasi dan UKM Puspayoga menegaskan bahwa saat ini UMKM harus benar-benar memanfaatkan internet sebagai bagian dari strategi pemasaran maupun branding produk (Supriadi, 2016). Puspayoga pun meyakini bahwa internet dapat meningkatkan penjualan produk UMKM, untuk selanjutnya diikuti dengan peningkatan produksi dan produktivitas UMKM. Tantangan kontinuitas dan kualitas produk yang dapat dihadapi dengan baik akan membuat UMKM sukses dan cepat berkembang.

Media sosial merupakan suatusarana digital marketing yang paling mudah untuk dimanfaatkan. Sebelum sebuah usaha memiliki situs, tidak jarang kita menemukan terutama di pasar seperti Indonesia bahwa mereka telah memulai memasuki ranah dunia maya melalui media sosial. Hal ini dapat menjadi stimulan perkembangan kewirausahawanan dan keberlangsungan UMKM. Selain biaya yang murah dan tidak perlunya keahlian khusus dalam melakukan inisiasi awal, media sosial dianggap mampu untuk secara langsung meraih (engage) calon konsumen. Oleh karena itu tidak heran bahwa pelaku usaha justru lebih menitikberatkan pemanfaatan media sosial dibanding dengan pengembangan sebuah situs.

Para pelaku UMKM tersebut terhadang kendala masih minimnya pengetahuan terhadap digital marketing dan electronic commerce (e-commerce). Potensi pemanfaatan digital marketing ini mengharuskan masyarakat untuk melek teknologi, oleh karena itu diperlukan sosialisasi dan pelatihan penggunaan teknologi informasi dan komunikasi ini. Kegiatan pengabdian masyarakat mengenai pemanfaatan digital marketing ini diharapkan dapat memberikan pengetahuan dan pemahaman serta dapat menginspirasi pelaku UMKM dalam memanfaatkan teknologi internet dan jejaring sosial sebagai alat untuk menjalankan bisnisnya.

Penulis dan tim tertarik untuk mengkaji sejauh mana pemanfaatan digital marketing yang telah dilakukan oleh pelaku UMKM di Kelurahan Malaka Sari, Kecamatan Duren Sawit, Jakarta Timur.Tim penyusun proposal mempunyai ide untuk menyelenggarakan kegiatan pengabdian masyarakat bertema "Pemanfaatan Digital Marketing bagi Usaha Mikro, Kecil, dan Menengah (UMKM) di Kelurahan Malaka Sari, Duren Sawit".

\section{Identifikasi dan Perumusan Masalah}

Berdasarkan uraian di atas, maka dapat diidentifikasi terdapat permasalahan sebagai berikut:

1. Terjadi peralihan tren pemasaran dari konvensional (offline) ke digital (online).

2. Jumlah pelaku usaha khususnya UMKM yang memanfaatkan digital marketing tidak sebanding dengan 
jumlah pertumbuhan pengguna internet.

3. Masih sedikit pelaku UMKM yang tidak paham bagaimana cara melakukan digital marketing dengan memanfaatkan jejaring sosial.

Identifikasi masalah yang telah disebutkan di atas membawa kita ke perumusan masalah berikut:

1. Sejauh mana pengetahuan dan pemahaman pelaku UMKM mengenai pentingnya digital marketing bagi usaha mereka?

2. Sejauh mana kemampuan pelaku UMKM dalam mempraktikkan digital marketing dengan memanfaatkan jejaring sosial?

\section{Tujuan Kegiatan}

Kegiatan pengabdian masyarakat ini bertujuan untuk:

1. Memberikan pengetahuan dan pemahaman kepada pelaku UMKM mengenai pentingnya digital marketing bagi usaha mereka;

2. Mengajarkan praktik digital marketing dengan memanfaatkan jejaring sosial kepada pelaku UMKM.

Kompetensi yang diharapkan tercapai dari kegiatan ini adalah:

1. Pengetahuan dan pemahaman pelaku UMKM yang menjadi peserta akan pentingnya digital marketing bagi usaha mereka;

2. Kemampuan pelaku UMKM yang menjadi peserta dalam mempraktikkan digital marketing dengan memanfaatkan jejaring sosial.

\section{Manfaat Kegiatan}

Adapun manfaat yang diperoleh dari kegiatan ini adalah:

a. Peserta

1. Pelaku UMKM yang menjadi peserta menjadi tahu dan paham akan pentingnya digital marketing bagi usaha mereka;

2. Pelaku UMKM yang menjadi peserta dapat mempraktikkan secara langsung digital marketing dengan memanfaatkan jejaring sosial;

3. Pelaku UMKM yang menjadi peserta dapat terinspirasi dan termotivasi untuk menggunakan digital marketing sebagai sarana komunikasi dan promosinya.

b. Tim Pengabdian Masyarakat

1. Memberikan kontribusi pengetahuan dan pengalaman kepada masyarakat khususnya pelaku UMKM sesuai dengan kompetensi yang dimiliki oleh instruktur;

2. Memahami praktik langsung pemanfaatan jejaring sosial dalam rangka peralihan cara promosi UMKM dari konvensional menuju digital marketing.

\section{KAJIAN TEORETIS \\ Digital Marketing}

Teknologi digital telah mengubah cara manusia dalam berkomunikasi, bertindak, dan mengambil keputusan. Aktivitas pemasaran pun tak lepas dari pengaruh teknologi digital. Istilah pemasaran berbasis digital (digital marketing) telah 
mengalami evolusi dari awalnya kegiatan pemasaran barang dan jasa yang menggunakan saluran digital hingga pengertian yang lebih luas yaitu proses memperoleh konsumen, membangun preferensi konsumen, mempromosikan merek, memelihara konsumen, dan meningkatkan penjualan.

Konsep digital marketing berasal dari internet dan mesin pencari (search engines) pada situs. Ketika penggunaan internet meledak di tahun 2001, pasar didominasi oleh Google dan Yahoo sebagai search engine optimization (SEO). Penggunaan pencarian melalui internet berkembang pada tahun 2006 dan pada tahun 2007 penggunaan perangkat mobile meningkat drastis yang juga meningkatkan penggunaan internet dan masyarakat dari berbagai penjuru dunia mulai berhubungan satu sama lain melalui media sosial (Khan \& Siddiqui, 2013).

Definisi digital marketing menurut American Marketing Association (AMA) adalah aktivitas, institusi, dan proses yang difasilitasi oleh teknologi digital dalam menciptakan, mengomunikasikan, dan menyampaikan nilai-nilai kepada konsumen dan pihak yang berkepentingan lainnya (Kannan \& Hongshuang, 2016).

Chaffey (2013) mendefinisikan digital marketing sebagai penggunaan teknologi untuk membantu aktivitas pemasaran yang bertujuan untuk meningkatkan pengetahuan konsumen dengan cara menyesuaikan dengan kebutuhan mereka.
Sawicky (2016) mengartikan digital marketing sebagai eksploitasi terhadap teknologi digital yang digunakan untuk menciptakan suatu saluran untuk mencapai resipien potensial untuk mencapai tujuan perusahaan melalui pemenuhan kebutuhan konsumen yang lebih efektif.

Digital marketing didefinisikan juga sebagai kegiatan pemasaran yang menggunakan media berbasis internet (Wardhana, 2015).Internet adalah alat yang cukup berpengaruh untuk bisnis. Roger dalam Rahardjo (2011) mengungkapkan ciri-ciri internet adalah sebagai berikut:

1. Interactivity, kemampuan perangkat teknologi memfasilitasi komunikasi antar individu seperti bertatap muka langsung. Komunikasi terjalin sangat interaktif sehingga para partisipan bisa berkomunikasi dengan lebih akurat, efektif, dan memuaskan.

2. Demassification, pesan dapat dipertukarkan kepada partisipan yang terlibat dalam jumlah besar.

3. Asynchronous, teknologi komunikasi mempunyai kemampuan untuk mengirimkan dan menerima pesan pada waktu yang dikehendaki setiap peserta.

Media sosial memungkinkan pelaku usaha untuk mencapai konsumen dan membangun hubungan yang lebih personal. Zhu dan Chen (2015) membagi media sosial ke dalam dua kelompok sesuai dengan sifat dasar koneksi dan interaksi: 
1. Profile-based, yaitu media sosial berdasarkan profil yang fokus kepada anggota individu. Media sosial kelompok ini mendorong koneksi yang terjadi karena individu tertarik kepada pengguna media sosial tersebut (e.g. Facebook, Twitter, WhatsApp).

2. Content-based, yaitu media sosial yang fokus kepada konten, diskusi, dan komentar terhadap konten yang ditampilkan. Tujuan utamaya adalah menghubungkan individu dengan suatu konten yang disediakan oleh profil tertentu karena individu tersebut menyukainya (e.g. Youtube, Instagram, Pinterest).

Media sosial telah membuka pintu bagi pelaku usaha untuk berkomunikasi dengan jutaan orang mengenai produk mereka dan telah menciptakan peluang pemasaran baru.

\section{Pemanfaatan Digital Marketing oleh Pelaku UMKM}

Media sosial berpotensi untuk membantu pelaku UMKM dalam memasarkan produknya (Stelzner, 2012).Media sosial didefinisikan sebagai sekelompok aplikasi berbasis internet yang menciptakan fondasi ideologi dan teknologi dari Web 2.0 yang memungkinkan penciptaan dan pertukaran user generated content (Stockdale, Ahmed, \& Scheepers, 2012). Aplikasi media sosial tersedia mulai dari pesan instan hingga situs jejaring sosial yang menawarkan pengguna untuk berinteraksi, berhubungan, dan berkomunikasi satu sama lain. Aplikasi-aplikasi ini bermaksud untuk menginisiasi dan mengedarkan informasi online tentang pengalaman pengguna dalam mengonsumsi produk atau merek, dengan tujuan utama meraih (engage) masyarakat. Dalam konteks bisnis, people engagement dapat mengarah kepada penciptaan profit.

Wardhana (2015) menemukan bahwa strategi digital marketing berpengaruh hingga $78 \%$ terhadap keunggulan bersaing UMKM dalam memasarkan produknya. Strategi tersebut terdiri dari:

1. Ketersediaan informasi produk dan panduan produk;

2. Ketersediaan gambar-gambar seperti foto atau ilustrasi produk;

3. Ketersediaan video yang mampu memvisualisasikan produk atau menampilkan presentasi pendukung;

4. Ketersediaan lampiran dokumendokumen yang berisi informasi dalam berbagai format;

5. Ketersediaan komunikasi online dengan pengusaha;

6. Ketersediaan alat transaksi dan variasi media pembayaran;

7. Ketersediaan bantuan dan layanan konsumen;

8. Ketersediaan dukungan opini online;

9. Ketersediaan tampilan testimonial;

10. Ketersediaan catatan pengunjung;

11. Ketersediaan penawaran khusus; 
12. Ketersediaan sajian informasi terbaru melalui SMS-blog;

13. Kemudahan pencarian produk;

14. Kemampuan menciptakan visibilitas dan kesadaran merek;

15. Kemampuan mengidentifikasi dan menarik pelanggan baru;

16. Kemampuan penguatan citra merek yang diterima oleh konsumen.

Pemanfaatan digital marketing memiliki beberapa keunggulan, antara lain:

- Target bisa diatur sesuai demografi, domisili, gaya hidup, dan bahkan kebiasaan;

- Hasil cepat terlihat sehingga pemasar dapat melakukan tindakan koreksi atau perubahan apabila dirasa ada yang tidak sesuai;

- Biaya jauh lebih murah daripada pemasaran konvensional;

- Jangkauan lebih luas karena tidak terbatas geografis;

- Dapat diakses kapanpun tidak terbatas waktu;

- Hasil dapat diukur, misalnya jumlah pengunjung situs, jumlah konsumen yang melakukan pembelian online;

- Kampanya bisa dipersonalisasi;

- Bisa melakukan engagement atau meraih konsumen karena komunikasi terjadi secara langsung dan dua arah sehingga pelaku usaha membina relasi dan menumbuhkan kepercayaan konsumen.

Di sisi lain, digital marketing pun memiliki kelemahan, di antaranya:
- Mudah ditiru oleh pesaing;

- Dapat disalahgunakan oleh pihakpihak tidak bertanggung jawab;

- Reputasi menjadi tidak baik ketika ada respon negatif;

- Belum semua orang menggunakan teknologi internet/digital.

Stockdale, Ahmed, dan Scheepers (2012) berhasil mengidentifikasi business value dari penggunaan media sosial bagi UMKM, seperti:

- Terciptanya saluran pemasaran yang berkelanjutan;

- Kenaikan pendapatan jangka pendek dan penjualan jangka panjang;

- Penurunan biaya advertising hingga $70 \%$;

- Reduksi dalam biaya pemasaran secara keseluruhan;

- Terciptanya competitive advantage;

- Kemudahan promosi lintas platform media sosial;

- Peningkatan popularitas merek dan produk;

- Pengenalan organisasi atau perusahaan ke masyarakat.

Sosialisasi strategi digital marketing dalam bentuk pemanfaatan media sosial sangatlah penting karena dapat memberi pengetahuan kepada para pelaku UMKM mengenai cara maupun tahapan dalam memperluas jaringan konsumen melalui pemanfaatan media sosial dalam memasarkan produknya sehingga 
dapat meningkatkan keunggulan bersaing bagi UMKM itu sendiri.

\section{METODOLOGI}

\section{Kerangka Pemecahan Masalah}

Kerangka atau tahapan dalam kegiatan sosialisasi ini adalah sebagai berikut:

\section{Analisis Kebutuhan}

Berdasarkan diskusi yang dilakukan oleh tim pengabdian masyarakat pada program kegiatan ini, masyarakat khususnya pelaku UMKM memerlukan program kegiatan ini dengan pertimbangan:

1) Kurangnya pengetahuan dan pemahaman pelaku UMKM mengenai pentingnya digital marketing bagi usaha mereka;

2) Kurangnya kemampuan pelaku UMKM dalam mempraktikkan digital marketing dengan memanfaatkan jejaring sosial.

\section{Rancangan Instruksional}

Dalam menentukan rancangan instruksional ini perlu dipertimbangkan aspek-aspek berikut:

1) Isi materi program kegiatan yang relevan dengan kebutuhan mereka. Tim pengabdian masyarakat ini telah memetakan kebutuhan materi keseluruhan bagi pelaku UMKM yang dibagi dalam dua materi kegiatan yangdijelaskan pada bagian materi kegiatan.

2) Latar belakang pelaku UMKMsepertiusia, jenis kelamin dan sebagainya.
3) Jenis usaha dan lama usaha yang digeluti.

\section{Tahap Pengembangan}

Pada kegiatan ini, tim pengabdian masyarakat berupaya mengembangkan kegiatan baik dalam hal penyampaian materi kegiatan, praktik,maupun tanya jawab atas materi yang disampaikan.

\section{Realisasi Pemecahan Masalah Pelaksanaan}

Kegiatan Pengabdian Masyarakat ini dilaksanakan pada hari Minggu tanggal 7 Mei 2017 bertempat di gedung Sony Sugema Colege yang berlokasi di Jl. Malaka Raya no.71 dan 75, RT.03/RW.06, Kelurahan Malaka Sari, Kecamatan Duren Sawit, Jakarta Timur. Waktu yang dialokasikan untuk kegiatan adalahlima jam. Kegiatan berlangsung jam 09.00 - 14.00 WIB.

\section{Khalayak Sasaran}

Peserta yang hadir dalam kegiatan ini sebanyak 13 orang pelaku UMKM di bertempat tinggal di sekitar Kelurahan Malaka Sari, Kecamatan Duren Sawit, Jakarta Timur. Seluruh peserta berjenis kelamin wanita dengan rentang usia 30 tahun hingga 51 tahun. Wanita dipilih sebagai sasaran kegiatan Pengabdian kepada Masyarakat ini dalam rangka membantu pemberdayaan wanita Indonesia terutama di bidang Usaha Mikro, Kecil, dan Menengah. Selain itu, pada umumnya wanita lebih tidak tanggap terhadap kemajuan teknologi 
dibandingkan dengan pria, sehingga diharapkan kegiatan ini dapat membantu pemahaman dan kemampuan praktik digital marketing. Platform media sosial yang diajarkan kepada peserta adalah Facebook dan Instagram. Hal ini mengacu pada hasil penelitian We are Social yang menyebutkan Facebook dan Instagram adalah media sosial peringkat dua dan tiga tertinggi yang paling banyak digunakan oleh masyarakat. Youtube yang berada di peringkat teratas tidak diajarkan dalam kegiatan Pengabdian kepada Masyarakat ini karena Youtube menggunakan video yang proses pembuatannya lebih sulit dimengerti daripada proses pembuatan media grafis atau foto seperti yang digunakan dalam Facebook dan Instagram.

Kegiatan ini terkait dengan instansi seperti Universitas Negeri Jakarta yang membiayai kegiatan Pengabdian kepada Masyarakat yang dilaksanakan oleh dosen-dosen sebagai sebuah kewajiban atas Tridharma Perguruan Tinggi serta pemerintah setempat mulai dari Kelurahan sampat tingkat Rukun Warga yang memberikan perizinan untuk kegiatan ini.

\section{Metode Kegiatan}

Metode kegiatan yang digunakan pada program kegiatan ini diharapkan dapat memberikan kemudahan kepada peserta kegiatan. Dalam kegiatan ini, metode yang digunakan adalah metode penjelasan, sharing, tanya jawab, diskusi dan praktik.

Pada metode penjelasan, setiap instruktur menyampaikan materi terkait dan membuat tampilan visual berupa slide power point yang ditampilkan ke layar dengan alat LCD proyektor. Modul ringkas kegiatan dan alat tulis dibagikan kepada peserta kegiatan agar peserta memiliki pegangan untuk dibaca yang dapat langsung ditambahkan dengan catatan-catatan yang mereka perlukan. Instruktur dalam menyampaikan penjelasan juga memasukkan unsur "sharing" atau berbagi pengalaman mengenai penggunaan digital marketing dalam promosi bisnis yang dimiliki instruktur sehingga dapat memberikan gambaran lebih jelas kepada peserta.

Pada metode praktik, peserta membawa perangkat elektronik (smartphone) mereka yang tersambung ke internet untuk sama-sama berlatih digital marketing. Peserta diajarkan bagaimana cara membuat akun media sosial, cara membuat materi posting yang menarik dan mudah dicari, dan kapan harus mengunggah post.

\section{Materi Kegiatan dan Instruktur}

Pada sesi awal, peserta diberikan penjelasan mengenai apa itu digital marketing, perkembangan digital marketing secara umum, keunggulan serta kelemahan dari pemanfaatannya. Dijelaskan pula media-media yang dapat digunakan untuk pemasaran secara digital untuk kemudian fokus kepada media sosial. Sesuai dengan hasil riset yang menyatakan Facebook 
dan Instagram berada pada peringkat dua dan tiga media sosial yang paling banyak digunakan di Indonesia, kedua platform media sosial ini kemudian dipilih sebagai media sosial yang dibahas dalam kegiatan Pengabdian kepada Masyarakat ini.

Pada sesi selanjutnya, peserta diajarkan cara membuat akun Facebook serta akun page Facebook. Setelah akun terbuat, peserta dijelaskan mengenai simbol-simbol yang terpampang di halaman beranda Facebook. Di sini pun diberikan arahan mengenai cara-cara mengunggah foto dan mengedit profil. Setelah itu peserta diajarkan langkahlangkah cara membuat pages pada Facebook. Pages dibutuhkan jika pemasaran ingin dilakukan secara serius. Peraturan Facebook melarang akun personal utk digunakan berjualan, selain itu pertemanan hanya terbatas untuk 5,000 orang. Sementara itu, pages Facebook memungkinkan followers yang tak terbatas, sifatnya untuk konsumsi publik, orang tidak perlu mendapat persetujuan untuk menjadi teman mengikuti berita terbaru dari kita.Setelah selesai dengan Facebook, penjelasan dilanjutkan ke pembuatan akun Instagram. Langkahlangkahnya hampir sama dengan pembuatan akun Facebook. Di sini juga diajarkan cara mengunggah dan mengedit foto, serta hal-hal lain yang berkaitan.

Beberapa tips diberikan untuk membuat postingan yang menarik, seperti penggunaan foto beresolusi tinggi agar gambar tetap jelas ketika diunggah, penggunaan tanda pagar (hashtag) yang relevan dan jelas, keterangan (caption) yang menarik yang biasanya memiliki inti cerita sendiri, dan pemilihan jam yang tepat untuk pengunggahan berita atau foto (pagi hari sekitar pukul 7-9, siang sekitar pukul 12-14, sore dan malam hari sekitar pukul 17-21), pengaturan jeda waktu "postingan".

Sesi terakhir kegiatan adalah tanya jawab tentang hal-hal yang masih belum dipahami oleh peserta, atau sekedar berkonsultasi dan meminta tips tentang digital marketingyang sesuai untuk bisnis yang sedang mereka jalankan.

Materi kegiatan yang disampaikan serta instruktur pada program kegiatan ini dirangkum pada tabel 1. 
Tabel 1

Materi Kegiatan dan Instruktur

\begin{tabular}{c|l|l|c}
\hline NO & \multicolumn{1}{|c|}{ MATERI } & \multicolumn{1}{|c}{ INSTRUKTUR } & WAKTU \\
\hline 1 & Pembukaan dan sambutan & $\begin{array}{l}\text { Ketua: Dr. Dedi Purwana E.S., } \\
\text { M.Bus. }\end{array}$ & 30 Menit \\
\hline 2 & Sosialisasi Digital Marketing & Rahmi, S.E., M.S.M. & 60 Menit \\
\hline 3 & $\begin{array}{l}\text { Pemanfaatan Digital Marketing } \\
\text { bagi pelaku UMKM melalui } \\
\text { aplikasi media sosial }\end{array}$ & Shandy Aditya, BIB, MPBS & 120 Menit \\
\hline 4 & $\begin{array}{l}\text { Sharing, tanya jawab, diskusi } \\
\text { Total Alokasi Waktu }\end{array}$ & $\begin{array}{l}\text { Dr. Dedi Purwana E.S., M.Bus. } \\
\text { Rahmi, S.E., M.S.M. } \\
\text { Shandy Aditya, BIB, MPBS }\end{array}$ & 90 Menit \\
\hline
\end{tabular}

\section{HASIL DAN PEMBAHASAN}

Peserta yang hadir sebanyak 13 orang, melebihi target awal 10 orang. Seluruh peserta berjenis kelamin wanita, berusia antara 30 hingga 51 tahun. Produk usaha mereka bervariasi dari mulai makanan, baju, tas, kue, hingga produk jasa seperti penulis cerita anak. Mereka telah menjalankan usaha selama 5 bulan hingga yang terlama 5 tahun.

Tabel 2

Data Peserta Kegiatan

\begin{tabular}{|c|c|c|c|c|c|c|}
\hline No. & Nama & Usia & Usaha & Nama Usaha & $\begin{array}{l}\text { Lama } \\
\text { Usaha }\end{array}$ & $\begin{array}{c}\text { Social Media } \\
\text { Marketing }\end{array}$ \\
\hline 1. & $\begin{array}{l}\text { Suryani } \\
\text { Mahditiari }\end{array}$ & 51 tahun & Kantin makanan & Rawon Pojok & 1 tahun & - \\
\hline 2. & $\begin{array}{l}\text { Rara Indri } \\
\text { Indrayanti }\end{array}$ & 41 tahun & $\begin{array}{l}\text { Katering tumpeng, } \\
\text { kebuli }\end{array}$ & Fiqy Catering & 5 tahun & $\begin{array}{l}\text { Facebook, } \\
\text { BBM, } \\
\text { WhatsApp }\end{array}$ \\
\hline 3. & Eva Dohar & 43 tahun & $\begin{array}{ll}\text { Pembuat kue } \\
\text { kering }\end{array}$ & Eva Cookies & 5 tahun & - \\
\hline 4. & $\begin{array}{l}\text { Dian } \\
\text { Puspalita }\end{array}$ & 30 tahun & $\begin{array}{l}\text { Penyalur baju dan } \\
\text { tas anak muslim }\end{array}$ & Afrakids & 2 tahun & $\begin{array}{l}\text { Facebook, } \\
\text { Instagram, } \\
\text { WhatsApp }\end{array}$ \\
\hline 5. & Yuyun & 42 tahun & $\begin{array}{l}\text { Titip jual kue basah } \\
\text { tradisional }\end{array}$ & $\begin{array}{ll}\text { Toko } & \text { Kue } \\
\text { Taman } & \\
\end{array}$ & 2 tahun & $\begin{array}{l}\text { Grup } \\
\text { WhatsApp }\end{array}$ \\
\hline 6. & $\begin{array}{l}\text { Amalia } \\
\text { Fadmi }\end{array}$ & 38 tahun & Hijab muslimah & - & 1 tahun & - \\
\hline 7. & Muslinawati & 31 tahun & $\begin{array}{l}\text { - Baju dan } \\
\text { perlengkapan }\end{array}$ & - GieSya Shop & 4 tahun & $\begin{array}{l}\text { Pernah } \\
\text { Facebook dan }\end{array}$ \\
\hline
\end{tabular}




\begin{tabular}{|c|c|c|c|c|c|c|}
\hline No. & Nama & Usia & Usaha & Nama Usaha & $\begin{array}{l}\text { Lama } \\
\text { Usaha }\end{array}$ & $\begin{array}{c}\text { Social Media } \\
\text { Marketing }\end{array}$ \\
\hline & & & $\begin{array}{l}\text { dapur } \\
\text { - Kue kering dan } \\
\text { kue basah }\end{array}$ & - GieSya Kue & & $\begin{array}{l}\text { Tokopedia, } \\
\text { masih BBM }\end{array}$ \\
\hline 8. & Mety Pujiati & 33 tahun & $\begin{array}{l}\text { Penulis buku cerita } \\
\text { anak }\end{array}$ & - & 5 tahun & - \\
\hline 9. & $\begin{array}{l}\text { Yayah } \\
\text { Murtafiah }\end{array}$ & 44 tahun & Penyalur tas etnik & - & 2 tahun & $\begin{array}{l}\text { Pernah OLX } \\
\text { dan Facebook }\end{array}$ \\
\hline 10. & $\begin{array}{l}\text { Sulis } \\
\text { Setianingsih }\end{array}$ & 30 tahun & Baju anak & Rizky Kids & 2 tahun & - \\
\hline 11. & $\begin{array}{l}\text { Wastiningsi } \\
\mathrm{h}\end{array}$ & 47 tahun & $\begin{array}{ll}\text { Penyalur } & \text { risol } \\
\text { mentah } & \end{array}$ & - & 5 bulan & - \\
\hline 12. & $\begin{array}{l}\text { Suryani } \\
\text { Wahyu H. }\end{array}$ & 44 tahun & Kantin makanan & Rawon Pojok & 1 tahun & - \\
\hline 13. & Risti & 40 tahun & MLM Herbal & Herbal HPAI & 5 bulan & - \\
\hline
\end{tabular}

Dari 13 orang peserta, baru 2 orang yang telah menggunakan media sosial secara aktif untuk memasarkan produk mereka. Platform media sosial utama yang mereka gunakan adalah Facebook karena platform ini yang paling familiar bagi mereka. Sebanyak 2 orang peserta lain pernah menggunakan media sosial untuk pemasaran produknya namun tidak mereka tekuni. Selain menganggap penggunaan digital marketing cukup sulit, mereka juga merasa tidak banyak transaksi aktual yang terjadi dibandingkan dengan berjualan langsung. Sebanyak 9 orang peserta lainnya belum pernah menggunakan media sosial sebagai sarana pemasaran. Mereka enggan untuk mencoba karena tidak paham dengan cara pembuatan dan penggunaannya, meski ada pula yang merasa usahanya tidak membutuhkan pemasaran secara digital.

Meski media sosial belum dimanfaatkan secara optimal, tapi para pelaku UMKM ini telah menggunakan media digital lain untuk proses transaksi. Mereka menggunakan aplikasi pesan singkat seperti WhatsApp dan BlackBerry Messenger untuk bertukar pesan, promosi, dan bertransaksi, serta menggunakan transfer elektronik (mobile banking, internet banking) untuk melakukan pembayaran.

\section{KESIMPULAN DAN SARAN}

Penggunaan teknologi digital telah memengaruhi semua aspek kegiatan manusia, termasuk pemasaran. Pemasaran berbasis digital digunakan untuk memperoleh konsumen, membangun preferensi mereka, promosi merek, memelihara konsumen, serta meningkatkan penjualan yang pada akhirnya meningkatkan profit.Digital marketing memungkinkan pembeli memperoleh seluruh informasi mengenai produk dan bertransaksi melalui internet, dan memungkinkan penjual untuk 
memantau dan menyediakan kebutuhan serta keinginan calon pembeli tanpa batasan waktu dan geografis. Digital marketing juga merupakan cara komunikasi dua arah yang dapat menimbulkan awareness dan engagement masyarakat terhadap produk dan merek tertentu.Platform yang sering digunakan untuk digital marketing adalah media sosial, terutama Facebook dan Instagram.

Perubahan perilaku pemasaran dari konvensional ke digital tidak diimbangi oleh keberadaan pelaku UMKM yang menggunakan digital marketing, padahal UMKM dipercaya mampu memacu perekonomian Indonesia. Pemanfaatan konsep pemasaran berbasis teknologi digital menjadi harapan bagi UMKM untuk berkembang menjadi pusat kekuatan ekonomi. UMKM dapat menggunakan media sosial sebagai sarana digital marketing. Selain biaya yang murah dan tidak perlunya memiliki keahlian khusus dalam melakukan inisiasi awal, media sosial dianggap mampu untuk secara langsung meraih konsumen.

Minimnya pengetahuan pelaku UMKM mengenai digital marketing menginspirasi tim Pengabdian kepada Masyarakat untuk menyampaikan sosialisasi dan memberikan pelatihan mengenai penggunaan teknologi informasi dan komunikasi ini. Jika pelaku UMKM paham akan pentingnya digital marketing bagi usaha mereka, diharapkan mereka akan termotivasi untuk menggunakan digital marketing sebagai sarana komunikasi dan promosinya, serta dapat mempraktikkannya secara langsung dengan memanfaatkan media sosial.

Dari pelaksanaan kegiatan Pengabdian kepada Masyarakat ini, diperoleh wawasan bahwa sesungguhnya para pelaku UMKM tertarik untuk menggunakan digital marketing dna memanfaatkan media sosial secara optimal, namun mereka menghadapi beberapa kendala. Kendala yang dihadapi contohnya adalah kurangnya pemahaman mengenai pentingnya digital marketing, kurangnya pengetahuan mengenai teknologi informasi dan komunikasi serta cara-cara penggunaan dan pemanfaatan media sosial yang baik, tidak sabar ingin segera mendapat hasil, serta kurangnya pemahaman untuk menciptakan "postingan" yang menarik.

Saran yang dapat disampaikan oleh tim Pengabdian kepada Masyarakat adalah pelatihan-pelatihan semacam ini perlu lebih sering dilaksanakan untuk membangun kesadaran dan pemahaman mengenai digital marketing dan langkah-langkah yang harus dilakukan untuk membuat dan mengelola akun media sosial, materi yang disampaikan disesuaikan dengan kemampuan para peserta, serta adanya evaluasi lanjutan setelah kegiatan guna mengetahui apakah materi yang disampaikan betul-betul dipraktikkan.

Di sisi lain, pelaku UMKM harus menumbuhkan keberanian untuk mencoba hal yang baru, berlaku 
profesional, dan sabar menunggu hasil sambil terus berkreasi. Dalam hal digital marketing dengan media sosial, pelaku UMKM sebaiknya:

1. Membuat akun media sosial untuk usaha yang terpisah dari akun pribadi;

2. Membuat nama akun yang sederhana, mudah diingat, menjelaskan tentang usahanya, dan memiliki nama yang sama dengan platform media sosial lain yang digunakan;

3. Post secara berkala dan rutin, disesuaikan dengan "golden moment";

4. Usahakan setiap post selalu berkaitan dengan usaha;

5. Buatlah tanda pagar (hashtag) unik yang mencirikan usaha kita dan gunakan itu di setiap post;

6. Jawab segala pertanyaan yang ditanyakan oleh follower untuk menandakan bahwa akun aktif.

Selain itu, perlu dukungan pula dari pemerintah misalnya kerja Kementerian Koperasi dan Usaha Kecil Menengah (UKM) bekerja sama dengan Kementerian Riset Teknologi dan Pendidikan Teknologi mengadakan pelatihan-pelatihan semacam ini, membuat komunitas bagi para pelaku UMKM untuk saling berinteraksi dan berbagi tips dan trik untuk digital marketing.

\section{DAFTAR PUSTAKA}

Kannan, P. K., \& Hongshuang, L. (2016). Digital Marketing: A Framework, Review and Research Agenda.
International Journal of Research in Marketing .

Kemp, S. (2017, February 16). Retrieved February 18, 2017, from http://wearesocial.com/:

http://wearesocial.com/blog/2017/0

2/digital-southeast-asia-2017

Khan, F., \& Siddiqui, K. (2013). The Importance of Digital Marketing: An Exploratory Study to Find The Perception and Effectiveness of Digital Marketing amongst The Marketing Proffesionals in Pakistan. Journal of Information Sytems and Operations Management , 1-8.

Maulana, Y. (2017, 2 6). http://swa.co.id/swa/csr-corner/.

Retrieved 2 17, 2017, from http://swa.co.id/:

http://swa.co.id/swa/csr-

corner/yuswohady-ukm-harus-

manfaatkan-perkembangan-digital

Rahayu, E. M. (2012, March 19). http://swa.co.id/swa/trends/marketing/.

Retrieved February 17, 2017, from http://swa.co.id/:

http://swa.co.id/swa/trends/marketi ng/digital-marketing-cara-

komunikasi-dua-arah-acer

Stelzner, M. (2012, April). How Marketers are Using Social Media to Grow Their Business.

Stockdale, R., Ahmed, A., \& Scheepers, H. (2012). Identifying Business Value from The Use of Social Media: An SME Perspective. Pacific Asia Conference on Information Systems. Association for Inforamtion System Electronic Library. 
Supriadi, C. (2016, November 16). Retrieved February 18, 2017, from http:/ / www.marketing.co.id: http://www.marketing.co.id/dukung -wirausaha-wanita-lewat-aplikasi-dbsbusinessclass/

Supriadi, C. (2016, October 21). Retrieved February 18, 2017, from http:/ / www.marketing.co.id/: http://www.marketing.co.id/menkop -puspayoga-ukm-harus-manfaatkaninternet/
Utomo, R. M. (2016, October 20). http://m.metrotonews.com/teknologi/newsteknologi/. Retrieved February 17, 2017, from metrotvnews.com: http://m.metrotvnews.com/teknologi /news-teknologi/GNGyEMrkpemanfaatan-digital-marketing-diindonesia-masih-minim

Wardhana, A. (2015). Strategi Digital Marketing dan Implikasinya pada Keunggulan Bersaing UKM di Indonesia. 